\title{
The Comparison of the Effects of Two Botulinum Toxin A Injection Methods, Follow the Pain and Fixed-site Fixed-dose, on Improving the Quality of Life and Headaches in Patients with Chronic Migraine: A Preliminary Randomized Clinical Trial
}

Íki Botulinum Toksin A Enjeksiyon Yönteminin, "A ğrıyı Takip Etme" ve "Sabit Yer Sabit Doz”, Kronik Migrenli Hastalarda Yaşam Kalitesinin ve Baş A ğrısının İyileştirilmesi Üzerine Etkilerinin Karşılaştırılması: Bir Randomize Klinik Ön Çalışma

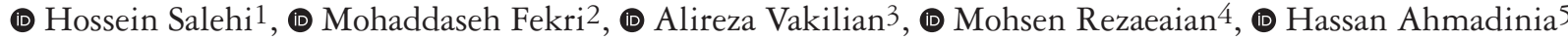 \\ 1Department of Plastic and Reconstructive Surgery, School of Medicine, Rafsanjan University of Medical Sciences, Rafsanjan, Iran \\ ${ }^{2}$ Clinical Research Development Center, Ali Ibn Abi Talib Hospital, Rafsanjan University of Medical Sciences, Rafsanjan, Iran \\ 3Department of Neurology, School of Medicine, Non-communicable Diseases Research Center, Rafsanjan University of Medical Sciences, \\ Rafsanjan, Iran \\ 4Department o Epidemiology and Biostatistics, Occupational Environmental Research Center, Rafsanjan Medical School, \\ Rafsanjan University of Medical Sciences, Rafsanjan, Iran \\ ${ }^{5}$ Department of Epidemiology and Biostatistics, Medical School, Rafsanjan University of Medical Sciences, Rafsanjan, Iran
}

\begin{abstract}
Objective: Migraine headaches are one of the most common and debilitating diseases. Chronic migraine (CM) is a type of migraine that reduces quality of life and causes disability. Botulinum toxin A (BT-A) was approved in 2010 by the Food and Drug Administration for CM as one of the treatment options. In BT-A treatment, follow the pain (FTP), fixed-site fixed-dose (FSFD) methods, and combined injections are prevalent. This clinical trial aimed to compare the effects of two methods of BT-A injections in patients with CM to determine the method with the fewest complications, the strongest therapeutic effects, and the lowest costs in improving quality of life.

Materials and Methods: In this preliminary clinical trial, 40 patients with CM were screened, and after examining the inclusion criteria, 18 patients completed the trial. After a baseline examination and experiencing a 28-day baseline period, they were randomly divided into FSFD and FTP groups. In our study, we used the Quality of Life Questionnaire, the Migraine Daily Note, and Headache Impact Test-6.

Results: A total of 17 women and 1 man completed the trial. Severity and rate of headaches and quality of life scores had better changes in the following months with similar trends in both groups without a significant difference.

Conclusion: The comparison of the scores showed an improvement in most patients, but there was no significant difference between the FSFD and FTP groups. However, the results indicated a greater response to the treatment and a higher rate of drug use in the FSFD group.

Keywords: Chronic migraine, botulinum toxin A, quality of life, method of injection

$\ddot{O} \mathbf{z}$

Amaç: Migren baş ağrıları en sık görülen ve zayıf düşüren hastalıklardan biridir. Kronik migren (KM), yaşam kalitesini düşüren ve maluliyete neden olan bir migren türüdür. Botulinum toksin A (BT-A), KM tedavisinde kullanılan tedavi seçeneklerinden biri olarak 2010 yılında Gıda ve İlaç Dairesi tarafından onaylandı. BT-A tedavisinde ağrıyı takip etme (ATE), sabit bölge sabit doz (SBSD) yöntemleri ve kombine enjeksiyonlar yaygın olarak kullanılır. Bu klinik çalışmada; en az komplikasyonu olan, en güçlü terapötik etkilere sahip ve yaşam kalitesini iyileştirmede en düşük maliyete sahip yöntemi belirlemek için KM’li hastalarda iki BT-A enjeksiyon yönteminin etkilerinin karşılaştırılması amaçlandı.

Gereç ve Yöntem: Bu ön klinik çalışmada, KM’li 40 hasta tarandı ve dahil edilme kriterleri incelendikten sonra 18 hasta çalışmayı tamamladı. Temel bir incelemeden sonra ve 28 günlük bir başlangıç dönemini tecrübe ettikten sonra, hastalar rastgele olarak ATE ve SBSD gruplarına ayrıldılar. Çalışmamızda Yaşam Kalitesi Anketi, Migren Günlük Notu ve Baş Ağrısı Etki Testi-6'yı kullandık.

Bulgular: Toplam 17 kadın ve 1 erkek çalışmayı tamamladı. Baş ağrısı şiddeti, sıklığı ve yaşam kalitesi skorları, her iki grupta da benzer eğilimlerle, anlamlı bir fark olmaksızın takip eden aylarda düzelme gösterdi.
\end{abstract}

Address for Correspondence/Yazişma Adresi: Alireza Vakilian MD, Department of Neurology, School of Medicine, Non-communicable Diseases Research Center, Rafsanjan University of Medical Sciences, Rafsanjan, Iran

Phone: +983431315000 E-mail: clinical.research85@ gmail.com ORCID: orcid.org/0000-0001-5413-5400

Received/Geliş Tarihi: 10.02.2020 Accepted/Kabul Tarihi: 28.05 .2020

${ }^{\oplus}$ Copyright 2020 by Turkish Neurological Society

Turkish Journal of Neurology published by Galenos Publishing House. 


\section{$\ddot{O} \mathbf{z}$}

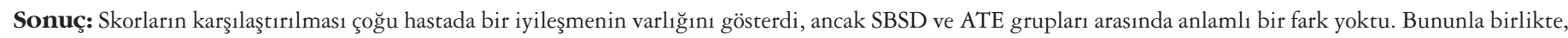
SBSD grubunda tedaviye daha iyi yanıt ve daha yüksek ilaç kullanım oranı gözlendi.

Anahtar Kelimeler: Kronik migren, botulinum toksini A, yaşam kalitesi, enjeksiyon yöntemi

\section{Introduction}

Migraine is a highly debilitating headache affecting 15 to $20 \%$ of the world population. There are many differences in the rate of migraine attacks among different people (1). Chronicity in migraine is one of the most serious conditions affecting patients' quality of life severely (2). Alternative treatments are recommended to people with chronic migraine (CM) who are resistant to three prophylactic drug groups. Until now, only botulinum toxin type A (BT-A) and topiramate have been specifically studied in chronic migraine. A review of the results of the third phase of two largescale trials called PREEMPT 1 and 2 within a 24-week period compared with a placebo group showed that BT-A improved the quality of life in patients with CM dramatically. BT-A is a good alternative and tolerable for patients resistant to three groups of prophylactic oral medications (3).

In October 2010, the United States Food and Drug Administration (FDA) approved BT-A as a treatment for CM (4). Three methods are common in BT-A injection, including fixed-site fixed-dose (FSFD), follow the pain (FTP), and a combined method. In FSFD, an injection is administered into seven muscles in the head and the neck at symmetric points, a prescribed dose is injected into five units at 31 sites, and a total of 155 units of BT-A is injected. In FTP, the dose and location of the injection depend on the areas where the patient feels pain and where the examiner notices tenderness. In this method, the injection is usually performed at asymmetric points. In the combined method, the injection is performed based on the FSFD injection using the FTP injection as a supplement (5). The majority of trials have so far focused on the effectiveness of BT-A in improving migraine. Therefore, few trials can be found comparing the effects of the two methods. FSFD has been used in most trials; therefore, we used FTP and compared the effects of the two methods.

The present study aimed to compare the effectiveness of FSFD and FTP in improving the quality of life in patients with CM and reducing the severity and frequency of their headaches.

\section{Materials and Methods}

\section{Study Design and Setting}

This preliminary clinical trial was conducted from February to July 2018 on patients with chronic migraine. The patients were selected from the Rafsanjan Specialty Center and the clinic owned by the team's neurologist. Patients eligible for an initial visit were summoned by the team's neurologist and entered a 28-day baseline period after they were reviewed for inclusion and exclusion criteria. In addition, written informed consent was obtained from the subjects.

\section{Participants}

The inclusion criteria comprised the experience of headache on 15 days or more in a 28 -day baseline period with each attack lasting for 4 hours or more and with $50 \%$ or most of the headache days with the headache being migraine-type or pseudo-migraine. The exclusion criteria any neuromuscular diseases, fibromyalgia, a mental illness that could interfere with the trial, Beck Depression Inventory scores higher than 24 , any previous exposure to a BT serotype, migraine with complications such as basilar migraine, ischemia, and other complications, primary or secondary headaches for other reasons, pregnancies, and the use of any preventive medications before the baseline period (Figure 1).

The sample size was calculated using the formula $\mathrm{n}=2 \mathrm{~s}^{2} \quad\left(\mathrm{z}_{1-\alpha / 2}+\mathrm{z}_{1-\beta}\right)^{2} / \mathrm{d}^{2}$, using $\alpha=0.05, \beta=0.1$ and difference between the means of two groups (the mean quality of life) and the common standard deviation $(\mathrm{d}=5.9, \mathrm{~S}=3.8)$ based on the results of a previous study. A 20-subject sample size (10 subjects in each group) was determined for the study. By considering a 30\% attrition rate, the final sample size for both groups was 28 (14 subjects in each group).

After the baseline period, the patients were randomly divided into two equal groups for FSFD and FTP injections by the simple randomization method using a random numbers table. The injections were performed by the team's plastic surgeon using an insulin syringe after distillation of the 100-unit vial of BT-A (dysport brand) with distilled water. In the FTP group, 25 units were injected at each tender point according to Table 1, and 155 units were injected at 31 fixed points in the FSFD group.

\section{Assessments}

After the injections, the patients were followed up for up to 4 periods every month by the team's neurologist without any information about the method of injection (Table 2). They also completed the Headache Impact test-6 (HIT-6), the questionnaires on the quality of life, and the Migraine Daily Note (MDN). The HIT-6 questionnaire, validated based on six questions covering the concept of pain contents and developed for episodic migraine, includes functional role, social functioning, energy and vitality, cognitive functioning, and psychological pain. The HIT-6 questionnaire was developed for episodic migraine, yet it was reliable for $\mathrm{CM}$.

The answer to each question was divided into six parts, including the points of "never six", "rarely eight", "sometimes 10 ", "often 11", and "always 13". The scores ranged from 36 to 78 , with the highest score related to the greatest effect of migraine headaches. Scores 49 and lower indicated no or lower effects, scores 50 to 55 indicated moderate effects, scores 56 to 59 indicated substantial effects, and scores 60 or higher indicated the most severe effects of migraine headaches (6). Yang et al. (7) validated 
this questionnaire. The 36-item short form survey (SF-36) is the most popular and most commonly used tool for measuring quality of life. It comprises 36 questions and 8 subscales. Each scale of the mentioned tool consists of 2 to 10 items.

Montazeri et al. (8) validated SF-36 questionnaire. The third criterion was designed based on MDN, which was used in one

Table 1. Trigger points checked for injection if needed in the FTP group

Trigger points

Site 1: Frontal

Site 2: Temporal

Site 3: Greater occipital

Site 4: Auriculotemporal

Site 5: Lesser occipital

Site 6: Isolated sites and nummular

FTP: Follow the pain clinical trial. MDN contains a table of 31 cells divided into five columns, including headache severity, associated symptoms, headache time, medications used in the acute phase, and headache relief.

\section{Statistical Analysis}

After data collection, the data were analyzed using the SPSS software. To describe the collected data, frequency tables, charts, and statistical indicators were utilized. In the statistical data analysis in this study, due to the abnormality of the population and the non-presence of the people at some times, the Mann-Whitney $\mathrm{U}$ test was used to compare the mean of the two groups, with the times compared using pairwise comparison. A p value less than 0.05 was considered statistically significant.

The study was approved by the Ethics Committee of Rafsanjan University of Medical Sciences under code: IR.RUMS. REC.1396.151, in accordance with the Helsinki Criteria.

This clinical trial was registered in the Iranian Registry of Clinical Trials(IRCT) under number:(IRCT 20180203038600N1).

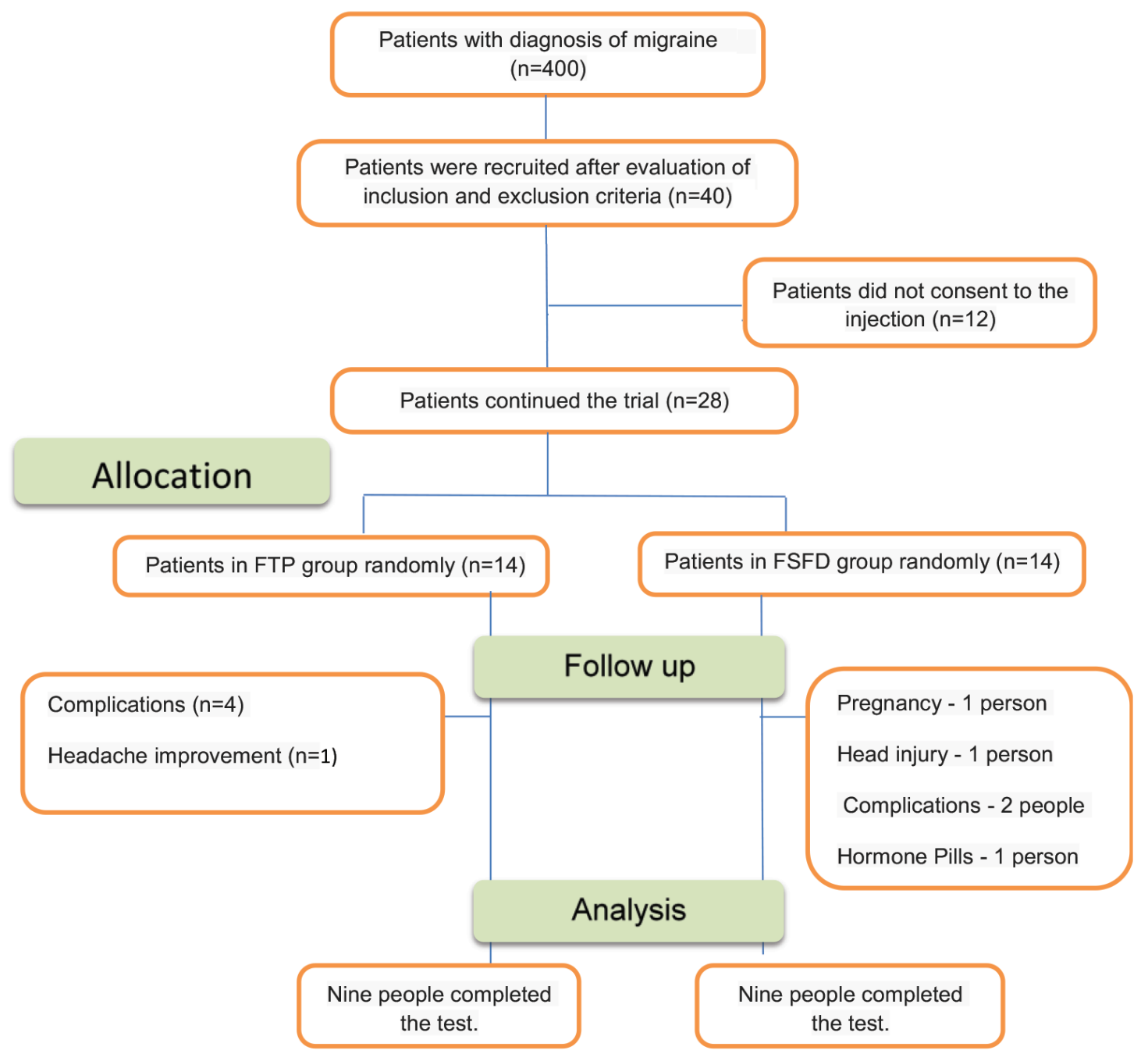

Figure 1. Flowchart of patients' selection

FSFD: Fixed-site fixed-dose, FTP: Follow the pain 


\section{Results}

Forty patients with CM were included in the present trial, 28 of whom completed the trial. Ten patients quit the trial owing to improvement in their headache, failure to respond to the treatment, development of complications, pregnancy, taking contraceptives, and head trauma (Figure 1).

Most of our patients used beta-blockers, tricyclic antidepressants and anticonvulsants such as valproate and topiramate in their history but not before the baseline study. About $80 \%$ of them had used non-steroidal anti-inflammatory drugs and triptans without consulting anyone, for more than 15 days per month (overuse medication).

The major comorbidity of our patients was mild depression and anxiety. Ninety percent of our patients in both groups had mild depression with no significant difference between them.

The patients who completed the trial included 17 women and one man of both Iranian and Afghan races aged 18 to 65 years. Table 3 shows the sex and race distributions of the patients. The patients were randomly divided into two equal groups of FTP and FSFD for injection purposes. After examining the patients in the FTP group, the number of tender points found by touching the head and neck areas of the patients included four points $(33.3 \%)$ for three patients and six points $(66.7 \%)$ for six patients.

After the injection, drug dosage was calculated in the patients injected with FTP, where according to the number of the tender points, three patients received 100 units (33.3), and six patients received 150 units $(66.7 \%)$. The average dosage administered was 133 units per person in the FTP group and 155 units in the FSFD group.
After the injection, the patients were followed up monthly for up to four months, and the data were collected on the headache rate, the quality of life, and headache severity, which were compared with the baseline data.

The examination of the MDN details in the two groups, based on comparing the number of headache days per month in both groups, showed a reduced mean number for the headache days from baseline to the last follow-up. However, the standard deviation of the headache days had an upward trend in the FTP group, except for the last follow-up. However, the standard deviation of the FSFD group was descending. According to the Mann-Whitney U test, there was no significant difference $(p>0.05)$ between the two groups, but the mean decrease in the number of the headache days had a significant difference from the previous month in each group (Table 4).

According to the analysis of the amount of medications used in the acute phase by the two groups, there was a downward trend in the FTP group in the mean use of acute-phase medications until the second follow-up, regardless of the number and type of the medications. The results of the Mann-Whitney $U$ test were not significantly different between the two groups ( $>0.05)$ (Table 5).

The evaluation results of the palliative effects of acute-phase medications on patients demonstrated that the respective mean had an oscillating trend in the FTP group, but it had an upward trend in the FSFD group. Likewise, the standard deviation in the FTP group had an oscillating trend. However, it showed an upward trend in the FSFD group due to the slight decrease in the second follow-up. The Mann-Whitney U test results were not significantly different between the two groups $(\mathrm{p}>0.05)$ (Table 6).

Table 2. Time Chart of Patient findings and follow-up

\begin{tabular}{|c|c|c|c|c|c|}
\hline n task & First month & \multirow[t]{2}{*}{ Second month } & \multirow[t]{2}{*}{ Fourth month } & \multirow[t]{2}{*}{ Fifth month } & \multirow[t]{2}{*}{ Sixth month } \\
\hline $\mathrm{CM}^{*}$ Patient finding & & & & & \\
\hline Baseline study*** & & & & & \\
\hline BT-A $^{* * *}$ injection & & & & & \\
\hline First month $\mathrm{FU}^{* * * * * * *}$ & & & & & \\
\hline Third month FU & & & & & \\
\hline Fourth month FU & & & & & \\
\hline $\begin{array}{l}{ }^{*} \text { Chronic migraine (basec } \\
{ }^{* * *} \text { Baseline study (checkin } \\
* * * * \text { Botulinum toxin A (on } \\
* * * * \text { Follow - up (assessed } \\
\text { CM: Chronic migraine, B }\end{array}$ & $\begin{array}{l}\text { on inclusion and e: } \\
\text { migraine daily not } \\
\text { group FSFD, secon } \\
\text { y checking SF-36, } \\
\text { A: Botulinum toxin }\end{array}$ & $\begin{array}{l}\text { Ion criteria) } \\
\text { ly and HIT- } 6 \text { and SF- } 36 \text { at the end the period) } \\
\text { bup FTP) } \\
\text { ine daily note and HIT- } 6 \text { ) } \\
\text { SFD: Fixed-site fixed-dose, FTP: Follow the pa }\end{array}$ & T-6: Headache Im & & \\
\hline
\end{tabular}

Table 3. Sexual and ethnic distribution of the two study groups

Variable

Sex

Female

Male

Race

Iranian

Afghan

FSFD: Fixed-site fixed-dose, FTP: Follow the pain
FTP

Number

8

1

7

2

\section{Percentage}

88.9

11.1

77.8

22.2
FSFD

Number Percentage

9

100.0

0

66.7

33.3 
According to the results of the quality of life questionnaire in the two groups, the mean score of the had an oscillating trend in the FTP group, but it had an upward trend in the FSFD group, except for the first follow-up. The standard deviation exhibited an oscillating trend in both the FTP and FSFD groups. The MannWhitney U test results were not significantly different between the two groups $(\mathrm{p}>0.05)$. In the FTP group, Figure 2 shows an upward trend, except for the last follow-up when the chart shows

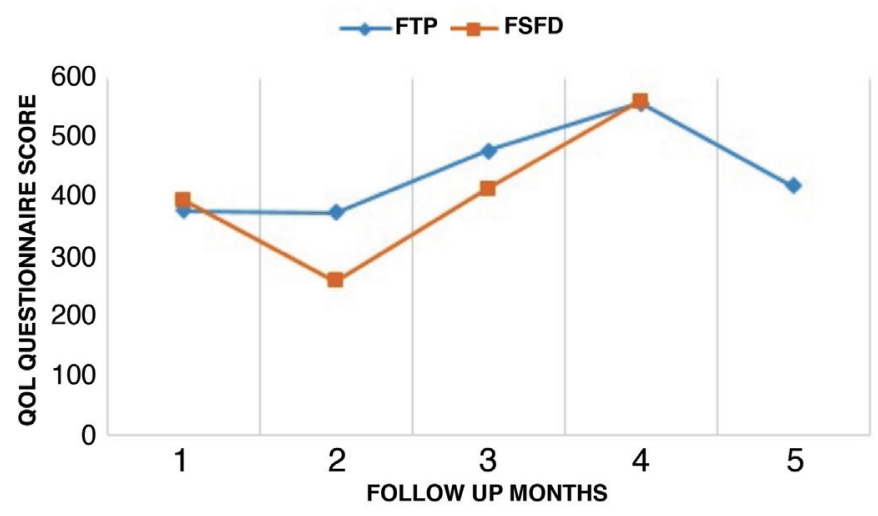

Figure 2. Quality of life score in patients with chronic migraine FSFD: Fixed-site fixed-dose, FTP: Follow the pain

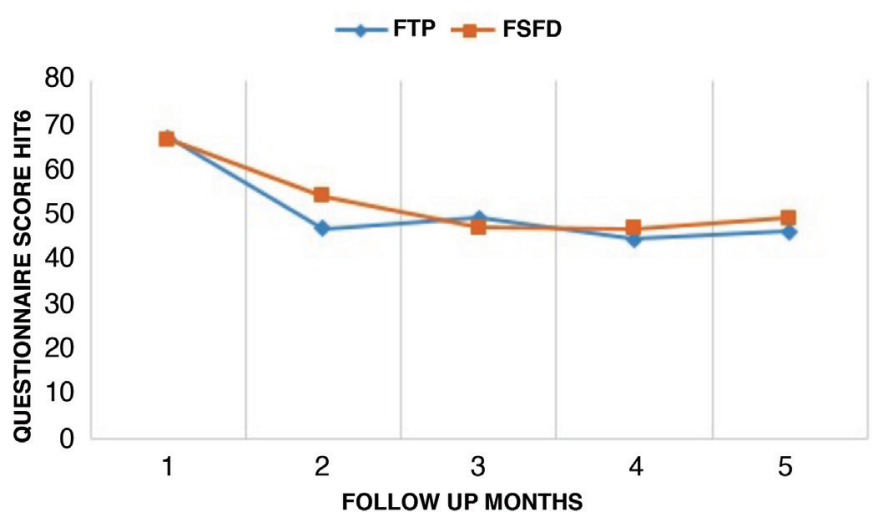

Figure 3. HIT-6 questionnaire score in patients FSFD: Fixed-site fixed-dose, FTP: Follow the pain, HIT-6: Headache Impact test-6 a downward trend. By contrast, in the FSFD group, Figure 3 showed a downward trend in the first follow-up accompanied by an upward trend.

On investigating the effects of headache severity on quality of life, according to the HIT-6 questionnaire used in the two groups, the mean score of the questionnaire showed an oscillating trend in the FTP group. Conversely, it showed a downward trend in the FSFD group, except for the last follow-up. The standard deviation in the FTP group was ascending; however, an oscillating trend was observed in the FSFD group. The Mann-Whitney U test results showed no significant difference between the two groups $(\mathrm{p}>0.05)$. Figure 3 shows a downward trend in the two groups, with minor differences.

The complications observed in the studied groups were highly transient. Improvements were made within two weeks after the injection. The most common complications were exacerbation of the headache a few days after the injection, raising of eyebrows, and feeling of neck pain.

\section{Discussion}

Despite the high prevalence of migraine, the disruption of the patients' quality of life, as well as the high socioeconomic and psychological costs to society caused by this disease, there is still no definitive treatment for it. The use of BT-A injection is a solution offered to prevent CM was approved by the US FDA; however, the best method of injection and its dosage is still unknown. In a recent study, we compared the effects of two common injection methods and their dosages. The high prevalence of CM in women is an evident point in the present study and all other studies. In the present study, there was a significant sex difference between the two groups of males and females, and the ratio of women to men was higher.

Almost all studies have shown the considerable effectiveness of BT-A in reducing the frequency of migraine headaches, except for a few studies that could not prove its therapeutic effects due to using a small number of subjects $(1,2,5)$. One study by Lee et al. (9) provided evidence of the response to BT-A treatment in the studied group by transcranial Doppler. Furthermore, in a study by Hubbard et al. (10), brain magnetic resonance imaging evidence of the responders concerning BT-A treatment showed a therapeutic effect even in the brain tissues. In the present study, the results of comparing headache rates in the subsequent follow-up to those of the pre-injection headache rates showed an improvement in the severity of headaches and the patients' quality of life compared with baseline.

Table 4. Comparison of the number of headache days between the two study groups

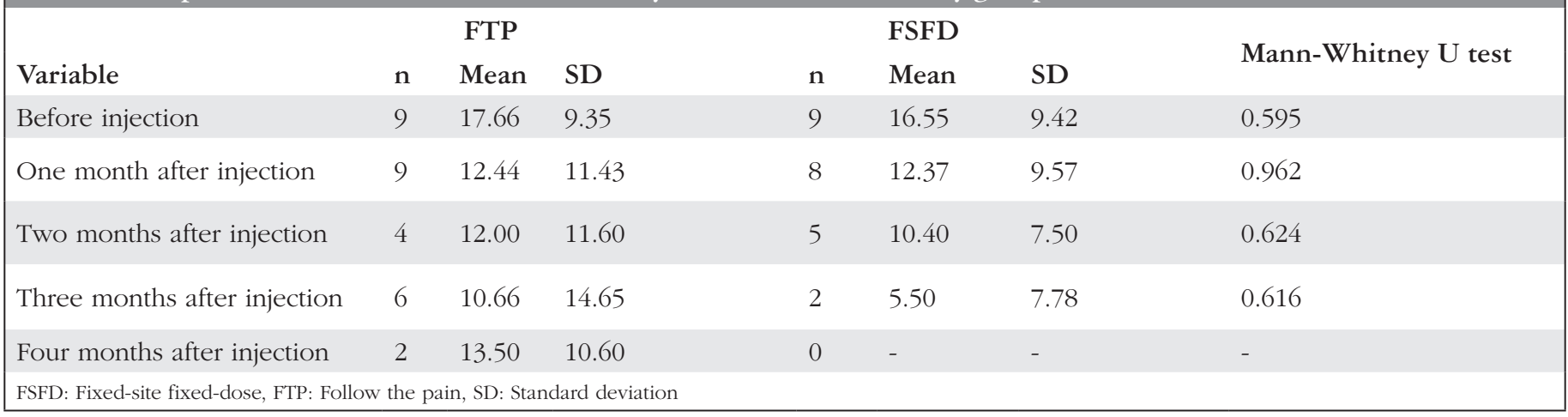


Table 5. Comparison of the amount of acute phase drug used between the two study groups

\begin{tabular}{|c|c|c|c|c|c|c|c|}
\hline \multirow[b]{2}{*}{ Variable } & \multicolumn{3}{|c|}{ FTP } & \multicolumn{3}{|c|}{ FSFD } & \multirow{2}{*}{$\begin{array}{l}\text { Mann- } \\
\text { Whitney U test }\end{array}$} \\
\hline & Number & Average & $\begin{array}{l}\text { Standard } \\
\text { deviation }\end{array}$ & Number & Average & $\begin{array}{l}\text { Standard } \\
\text { deviation }\end{array}$ & \\
\hline Before injection & 7 & 18.28 & 22.63 & 9 & 27.00 & 25.61 & 0.490 \\
\hline One month after injection & 7 & 13.14 & 23.06 & 8 & 16.25 & 20.41 & 0.403 \\
\hline Two months after injection & 4 & 21.50 & 28.44 & 5 & 37.00 & 23.83 & 0.317 \\
\hline Three months after injection & 6 & 15.00 & 25.10 & 2 & 35.50 & 34.65 & 0.211 \\
\hline Four months after injection & 2 & 9.00 & 9.90 & 0 & - & - & - \\
\hline
\end{tabular}

Table 6. Comparison of response rate to acute-phase drugs during the days after injection between the two study groups

\begin{tabular}{|c|c|c|c|c|c|c|c|}
\hline \multirow[b]{2}{*}{ Variable } & \multicolumn{3}{|c|}{ FTP } & & \multicolumn{2}{|l|}{ FSFD } & \multirow[b]{2}{*}{ Mann-Whitney U test } \\
\hline & $\mathrm{n}$ & Mean & SD & $\mathrm{n}$ & Mean & SD & \\
\hline Before injection & 9 & 15.33 & 11.22 & 9 & 11.11 & 7.62 & 0.374 \\
\hline One month after injection & 9 & 22.55 & 18.22 & 8 & 19.00 & 20.69 & 0.413 \\
\hline Two months after injection & 4 & 17.50 & 16.11 & 5 & 29.80 & 20.42 & 0.268 \\
\hline Three months after injection & 6 & 18.00 & 18.20 & 2 & 35.50 & 34.65 & 0.314 \\
\hline Four months after injection & 2 & 14.00 & 18.38 & 0 & - & - & - \\
\hline
\end{tabular}

CM has a severe negative effect on quality of life Blumenfeld et al. (11) and Wang et al. (12). Escher et al. (13) found better quality of life after BT-A use in their patients. There is no difference between medication overuse and other types of $\mathrm{CM}$ in response to BT-A. Our study showed better quality of life scores with BT-A injections in both groups. Most of our patients had overuse medication in their treatment and it was similar between the groups.

Reviewing the literature on the effects of BT-A on the recovery of chronic migraine, it was noted that few studies had compared methods of injection. In reviewing the studies conducted since 2.000 on BT-A injections in patients with CM, most of the studies had used a combined method and FSFD. In addition, Naprienko et al. (14) employed a combined method and FSFD, as well as comparing two different doses. According to their results, the higher the dose of BT-A injections, the higher the rate of improvement in patients' headaches, consistent with the results of the present study. Although the treatment response may have been different in the aforementioned study due to the injection method, not due to the dosage used, the studies by Negro et al. (15) and Andreou et al. (16) showed no difference in the studied groups in the increase in the therapeutic efficacy of Botox with an increase in the dose and a change in the method of injection. In this study, after collecting patients' baseline data, as well as injecting and following up patients for up to four months, no significant difference was found between the two groups in terms of quality of life or the severity and number of days of headache. In the present study, the patients were selected from two different races, resulting in a stronger therapeutic response in Afghan patients than in Iranian patients. In the present study, the age range of the target group was 18-65 years, similar to other studies. As already discussed, the 25-unit dose of UK Dysport was injected at tender points in the FTP group. In this study, the results for the FSFD group were better, but they were not statistically significant

Among the recent studies, Blumenfeld et al. (17) review considered the most studies about BT-A injection methods for CM. In this review, most of the recent BT-A injection methods were reviewed and showed that this treatment was safe and adverse effects were not permanent. Most of these studies used the FTP method in addition to the FSFD method (combination method), different from our study where we used FTP as a separate injection method in comparison with the FSFD method.

Behmand et al. (18) discovered strong evidence of the therapeutic effects for BT-A by injecting into the corrugator supercilii muscle using the FTP method; however, no comparison was made with FSFD in this study. Finally, by reviewing the respective literature, one could argue that this study was among the few studies comparing the effects of conventional BT-A injection methods.

Numerous studies have shown that a single injection of BT-A does not cause an appropriate therapeutic response; therefore, repeated injections are required in every 12 weeks. After the third injection in some patients, they confirmed the dramatic effects of BT-A; thus, one could claim that BT-A is a good long-term maintenance medication to treat patients with $\mathrm{CM}$ and even for those who do not respond to the first and second stages of the treatment. In addition, after repeated injections and long-term treatment, patients may respond to the treatment. Sarchielli et al. (19) also observed these results in their study. In phase one of the PREEMPT study, after two periods of injections, some criteria, including the number of headaches showed no improvement; 
however, after continued injections in stages 3 to 5, the analysis of all criteria was in favor of the BT-A injection (20).

In a study about patient adherence to preventive drug prescription, the authors found that three-quarters of the patients stopped their drugs and changed it during a one-year period (21). Another study showed that one-third of patients were nonadherent due to adverse effects and other causes (22). We also had a lack of cooperation of our patients, as shown in the flow chart of our study.

\section{Study Limitations}

Some of the limitations of this study included the lack of awareness among the subjects and the fear of the injection of a drug without having prior information, particularly injecting it in visible places, such as the hands and face. The injection pain, especially in the neck, as well as the adverse effects of the drug increased the fear of the injections. Many of the patients included in this study quit the trial due to the worsening of their headache in the first few days of the injection. The small size of the statistical population, high dropout rate of the subjects, and the lack of cooperation on the part of the patients resulted in losing some information.

Among the other limitations of this study was the irresponsibility of the patients in completing the questionnaires and not responding to the follow-up. Furthermore, the questionnaires used were among the other limitations of this trial because they were difficult to complete during the study days. Moreover, the HIT-6 questionnaire and the MDN led to more ambiguity of the answers.

\section{Suggestions}

Spending more time on introducing BT-A, its adverse effects, and its therapeutic effects will reduce the dropout rate in patients considerably. Additionally, conducting a study with a larger statistical population in the event of high dropout rates of patients could have less impact on the validity of the study results. A crosssectional study could provide a better comparison between groups, and the possibility of blinding patients with a placebo could prevent bias. In future studies, it is recommended that longer multiple injections and study periods be considered given the long-term effects of BT-A and the occurrence of therapeutic effects after the third injection, as well as the need for repeated injections to observe the effects of BT-A. Modification to and design of a new questionnaire more understandably and pragmatically will yield more accurate results.

\section{Conclusion}

Owing to the high dropout rate among the patients and the inadequate cooperation of a large number, a significant difference could not be established between the two groups in favor of one injection method. Hence, it is recommended that further trials be conducted in line with the aim of this trial. However, based on the report of the improvement trend in headaches in a large number of the patients, it is suggested that BT-A be considered a suitable alternative to improve the quality of life and decrease headache days, MDN scores, and HIT-6 scores in patients with CM. Between the two methods of injection, the FSFD group had better non-significant results than the FTP group.

\section{Acknowledgements}

The authors would like to thank the Clinical Research Development Unit for its support and collaboration in Ali Ibn Abitaleb hospital, Rafsanjan University of Medical Sciences, Rafsanjan, Iran.

Ethics

Ethics Committee Approval: The study was approved by the Ethics Committee of Rafsanjan University of Medical Sciences under code: IR.RUMS.REC.1396.151, in accordance with the Helsinki Criteria.

Informed Consent: Written informed consent was obtained from the subjects.

Peer-review: Externally peer-reviewed.

\section{Authorship Contributions}

Concept: H.S., A.V., M.F., Design: H.S., A.V., M.F., M.R.. H.A., Data Collection or Processing: H.S., A.V., M.F., Analysis or Interpretation: H.S., A.V., M.R., H.A., Literature Search: H.S., A.V., M.F., Writing: H.S., A.V., M.F., M.R., H.A.

Conflict of Interest: No conflict of interest was declared by the authors.

Financial Disclosure: Deputy Chairman of the Research department of Rafsanjan University of Medical Sciences for financial support.

\section{References}

1. Ion I, Renard D, Le Floch A, et al. Monocentric prospective study into the sustained effect of incobotulinumtoxin A (XEOMIN $((\mathrm{R}))$ ) botulinum toxin in chronic refractory migraine. Toxins (Basel) 2018;10:221.

2. Szok D, Csáti A, Vécsei L, Tajti J. Treatment of chronic migraine with onabotulinumtoxin A: mode of action, efficacy and safety. Toxins (Basel) 2015;7:2659-2673.

3. Cady RK, Schreiber CP, Porter JA, Blumenfeld AM, Farmer KU. A multi-center double-blind pilot comparison of onabotulinumtoxin $\mathrm{A}$ and topiramate for the prophylactic treatment of chronic migraine. Headache 2011;51:21-32.

4. Darroff RB, Mazziotta JC, Jankovic J, Pomeroy SL. Bradley's Neurology in Clinical Practice. 7th ed. London: Elsevier, 2015.

5. Guyuron B. Migraine Surgery. 1st ed. New York: Thieme, 2018.

6. Lipton RB, Varon SF, Grosberg B, et al. Onabotulinumtoxin A improves quality of life and reduces impact of chronic migraine. Neurology 2011;77:1465-1472.

7. Yang M, Rendas-Baum R, Varon SF, Kosinski M. Validation of the Headache Impact Test (HIT-6TM) across episodic and chronic migraine. Cephalalgia 2011;31:357-367.

8. Montazeri A, Goshtasebi A, Vahdaninia M, Gandek B. The short form health survey (SF-36): translation and validation study of the Iranian version. Qual Life Res 2005;14:875-882.

9. Lee MJ, Lee C, Choi H, Chung CS. Factors associated with favorable outcome in botulinum toxin A treatment for chronic migraine: a clinicbased prospective study. J Neurol Sci 2016;363:51-54.

10. Hubbard CS, Becerra L, Smith JH, et al. Brain changes in responders vs. non-responders in chronic migraine: markers of disease reversal. Front Hum Neurosci 2016;10:497.

11. Blumenfeld A, Varon S, Wilcox T, et al. Disability, HRQoL and resource use among chronic and episodic migraineurs: results from the International Burden of Migraine Study (IBMS). Cephalalgia 2011;31:301-315.

12. Wang SJ, Wang PJ, Fuh JL, Peng KP, Ng K. Comparisons of disability, quality of life, and resource use between chronic and episodic migraineurs:a clinic-based study in Taiwan. Cephalalgia 2013;33:171-181.

13. Escher CM, Paracka L, Dressler D, Kollewe K. Botulinum toxin in the management of chronic migraine: clinical evidence and experience. Ther Adv Neurol Disord 2017;10:127-135. 
14. Naprienko MV, Smekalkina LV, Surnova EA. Efficacy of different doses of botox in treatment of chronic migraine. Zh Nevrol Psikhiatr Im S S Korsakova 2017;117:44-48.

15. Negro A, Curto M, Lionetto L, Crialesi D, Martelletti P. Onabotulinumtoxin A $155 \mathrm{U}$ in medication overuse headache: a two years prospective study. Springerplus 2015;4:826.

16. Andreou AP, Trimboli M, Al-Kaisy A, et al. Prospective real-world analysis of Onabotulinumtoxin $A$ in chronic migraine post-National Institute for Health and Care Excellence UK technology appraisal. Eur J Neuro 2018;25:1069-e83.

17. Blumenfeld A, Silberstein SD, Dodick DW, et al. Method of injection of onabotulinumtoxin A for chronic migraine: a safe, well-tolerated, and effective treatment paradigm based on the PREEMPT clinical program. Headache 2010;50:1406-1418.

18. Behmand RA, Tucker T, Guyuron B. Single-site botulinum toxin type $A$ injection for elimination of migraine trigger points. Headache 2003;43:1085-1089.
19. Sarchielli P, Romoli M, Corbelli I, et al. Stopping onabotulinum treatment after the first two cycles might not be justified: results of a real-life monocentric prospective study in chronic migraine. Front Neurol 2017;8:655.

20. Aurora SK, Dodick DW, Turkel CC, et al. Onabotulinumtoxin A for treatment of chronic migraine: results from the double-blind, randomized, placebo-controlled phase of the PREEMPT 1 trial. Cephalalgia 2010;30:793803.

21. Rahimtoola H, Buurma H, Tijssen CC, Leufkens HG, Egberts AC. Migraine prophylactic medication usage patterns in The Netherlands. Cephalalgia 2003;23:293-301.

22. Linde M, Jonsson P, Hedenrud T. Influence of disease features on adherence to prophylactic migraine medication. Acta Neurol Scand 2008;118:367372. 